\title{
At the Brink of Nuclear War: Feasibility of Retaliation and the U.S. Policy Decisions During the 1962 Cuban Missile Crisis
}

\author{
Yang Gyu Kim \\ Florida International University
}

Félix E. Martín

Florida International University

\begin{abstract}
Recent studies in nuclear deterrence show that nuclear punishment is infeasible in most cases due to the opponent's second-strike capability, tactical redundancy, and the logic of self-deterrence. However, if the challenge against nuclear deterrence is expected to go unpunished, the deterrent policy is not credible and will likely fail. Can the defender violently punish the challenger possessing nuclear weapons? If it can, under what conditions? Thanks to President Kennedy's tape recordings, the Cuban Missile Crisis provides researchers an exceptional laboratory for testing various theories on the defender's policy choices after deterrence failure. This article derives a research hypothesis and its competing counterpart and examines their respective explanatory power via a process-tracing analysis of key members within the Executive Committee during the crisis. The study finds that the challenger's feasibility of retaliating with atomic weapons is a crucial predictor for the defender's policy choices.
\end{abstract}

Keywords: Deterrence, nuclear weapons, Cuban Missile Crisis, credibility, feasibility

\section{Introduction}

The Cold War generated multiple political and military showdowns between the Americans and the Soviets. They contended for geostrategic superiority and political influence in Greece, Germany, Korea, Hungary, Cuba, Czechoslovakia, and Afghanistan. All these crises heightened the intensity of their systemic rivalry to unprecedented levels. However, none was as extreme, frightening, or threatening to humanity as the 1962 Cuban Missile Crisis. This crisis was unique because it brought the world to the brink of nuclear war. Besides U.S. General MacArthur's 1951 proposal to President Truman to bomb China and resort to atomic weapons in the Korean War - a suggestion immediately rejected by the Presidentthe specter of a nuclear war was never as real until then, nor has it been since. The resolution of the Cuban Missile Crisis brought pause to the superpower rivalry, and it probably saved the world from complete annihilation.

Yang Gyu Kim, Visiting Scholar, Arnold A. Saltzman Institute of War and Peace Studies, Columbia University; Adjunct Professor, Department of Politics and International Relations, Florida International University. Email: ygk2002@columbia.edu; ykim027@fiu.edu. (10)0000-0002-9684-1538.

Félix E. Martín, Associate Professor, Department of Politics and International Relations, Florida International University. Email: martinf@fiu.edu and Fem1@columbia.edu. (10) 0000-0002-1716-5202. 
Notwithstanding this positive outcome, world citizens still live in an international state system where several countries possess sufficient nuclear firepower to cause a cataclysmic disaster. Given the current references to a new Cold War between China and the U.S., the uncertainty of the first nuclear multipolar system in history, and tensions in the Sino-Indian and Indo-Pakistani borders, it is instructive to investigate how American decision-makers reacted to Moscow's attempt to revise the status quo, and how their group-thinking evolved over two weeks, prompting the reformulation of a firm, new policy against the Soviet infringement in Cuba. This article focuses on this theme, seeking to discuss the implication of the crisis for nuclear deterrence literature.

Rational deterrence is a central theoretical notion in the study of war and peace in International Relations. Its prominence increased exponentially with the invention and proliferation of nuclear weapons, which raised the specter of a potential U.S.-Soviet nuclear showdown during the Cold War. The added urgency to understand and prevent a nuclear war produced an instant and keen interest among academics, policy circles, and the general public about deterrence theory and practice. Subsequently, the "four waves" of deterrence literature significantly advanced the understanding of the conditions necessary for a successful operation of a deterrent threat, such as short-term military balance, costly signaling, domestic audience costs, and reputation for resolve, which could purportedly dissuade a revisionist state from initiating an attack. ${ }^{2}$

Nuclear weapons have been treated as a special instrument of deterrence with their unprecedented capability to inflict unacceptable damage. Accordingly, the traditional deterrence literature, especially the Nuclear Revolutionists mentioned below, regards nuclear weapons as the ultimate means to buttress a deterrent policy. However, various studies in the Nuclear Pessimist tradition show that nuclear punishment or retaliation is infeasible in most cases due to the opponent's second-strike capability, tactical redundancy, and the logic of self-deterrence. In this vein, if the challenger's defiance against nuclear deterrence is expected to go unpunished by the defender, then the deterrent policy is not credible and, thus, will likely fail. Consequently, the following questions about the possible aftermath of deterrence failure are pertinent: Can the defender violently punish the challenger possessing nuclear weapons? If it can, under what conditions?

This article provides answers to these two crucial questions by tracing who suggested which policy during the American deliberation process of the Cuban Missile Crisis. First, teasing out the theoretical implications of deterrence theory, it derives a testable hypothesis and its competing counterpart from the literature. Second, the article uses the Cuban Missile Crisis as the litmus test for the analysis. Given the presumable failure of the American deterrence threat in October 1962, the article focuses only on the American side of the decision-making process during the crisis. Accordingly, the study examines the evolution of the thinking process of key members of the Executive Committee from the beginning of the Crisis to its decision to quarantine Cuba on October 20, 1962. Finally, the article presents the conclusions of the analysis as well as the associated theoretical and policy implications.

1 Robert Jervis, "Deterrence Theory Revisited," World Politics 31, no. 2 (1979): 289-324; Jeffrey W. Knopf, "The Fourth Wave in Deterrence Research," Contemporary Security Policy 31, no. 1 (2010): 1-33.

2 Paul Huth, "Deterrence and International Conflict: Empirical Findings and Theoretical Debates," Annual Review of Political Science 2, no. 1 (1999): 27. 


\section{Theoretical Discussion: Policy Choices After General Deterrence Failure}

\section{1. The understudied topic: Policy dynamics after deterrence failure}

Deterrence literature has focused on conditions for general or immediate deterrence success. There are two approaches in the literature: Rational and Cognitive Deterrence theories. A more prominent approach is the Rational Deterrence perspective, ${ }^{3}$ which in turn contains four models: (1) the Classical Rational Deterrence, ${ }^{4}$ (2) the Costly Signaling; ${ }^{5}$ (3) the Inherent Credibility; ${ }^{6}$ and (4) the Feasible Punishment ${ }^{7}$ models. They share one fundamental assumption: The defender's deterrent threat is most likely to succeed when the opponent considers it credible. Nonetheless, divergence emerges from how each model defines threat credibility. ${ }^{8}$ The comprehensive list of significant variables for deterrence success includes (1) "offensive military capability;" (2) "probability of victory;" (3) "interest at stake;" (4) "war cost;" (5) "audience cost;" and (6) "military/political feasibility of punishment."

Few attempts, however, have been made to identify conditions for the defender's policy choice to respond to deterrence failure. This result is possible because, during the Cold War, failure was considered as the ending point of strategic exchanges: nuclear war and humanity's annihilation. Notable exceptions are Huth and Russett, ${ }^{9} \mathrm{Wu},{ }^{10}$ and Danilovic. ${ }^{11}$ These studies assume that the same independent variables suggested by the general deterrence theory will define the policy dynamics after the general deterrence failure. That is, the more credible the deterrer is, the more likely it will respond to the failure with crisis escalation from general deterrence to immediate deterrence and, ultimately, war. For example, the defender is more likely to punish the challenger militarily in a favorable short-term balance of forces if the expected utility of war exceeds the capitulation payoff, and when there is high interest at

\footnotetext{
3 Huth, "Deterrence and International Conflict," 28.

John Orme, "Deterrence Failures: A Second Look," International Security 11, no. 4 (1987): 96-124; Paul K. Huth, "Extended Deterrence and the Outbreak of War," The American Political Science Review 82, no. 2 (1988): 423-43; Paul K. Huth and Bruce Russett, "Testing Deterrence Theory: Rigor Makes a Difference," World Politics 42, no. 4 (1990): 466-501; and Frank P. Harvey, "Practicing Coercion: Revisiting Successes and Failures Using Boolean Logic and Comparative Methods," Journal of Conflict Resolution 43, no. 6 (1999): 840-71.

James D. Fearon, "Signaling Foreign Policy Interests: Tying Hands versus Sinking Costs," Journal of Conflict Resolution 41 (1997): 68-90; Frank C. Zagare and D. Marc Kilogue, Perfect Deterrence (New York: Cambridge University Press, 2000); Branislav L Slantchev, "Military coercion in interstate crises," American Political Science Review 99, no. 4 (2005): 533-47; and Branislav L Slantchev, Military Threats: the Costs of Coercion and the Price of Peace (New York: Cambridge University Press, 2011).

6 Alexander George and Richard Smoke, Deterrence in American Foreign Policy (New York: Columbia University Press, 1974); and Danilovic, When the Stakes Are High.

Roseanne W. McManus, Statements of Resolve: Achieving Coercive Credibility in International Conflict (Cambridge: Cambridge University Press, 2017).

8 The Classical Rational Deterrence model suggests that a threat is considered credible when the attacker believes that the defender possesses "the military capabilities to inflict substantial costs on an attacker in an armed conflict" and that "the defender is resolved to use its available military forces." Huth, "Deterrence and International Conflict," 29. However, the Costly Signaling model, argues that capability and credibility are two very different concepts that need to be analyzed separately. Stephen L. Quackenbush, "Deterrence Theory: Where Do We Stand?," Review of International Studies 37, no. 2 (2011): 761. This leads them to drop the capability dimension in defining the concept of the threat credibility and to argue that threat credibility shall be "determined by a state's preference between conflict and backing down." Zagare and Kilgour, Perfect Deterrence, 83; and Quackenbush, "Deterrence Theory," 747. The "tying hands" strategy is a way to enhance threat credibility in this regard. Fearon, "Signaling Foreign Policy Interests" and Slantchev, Military Threats. Meanwhile, the Inherent Credibility model highlights that the interest at stake "shapes the opponent's perception of the deterrer's resolve." Danilovic, When the Stakes Are High, 5. Thus, it is impossible to enhance the credibility of a deterrent threat if it is for protecting a non-vital and unimportant national stake. Lastly, the Feasible Punishment model criticizes the signaling model for its attempt to focus merely on "costs of making or backing down from the statements" and emphasizes the importance of the ability to follow through on threats in enhancing the credibility of threats. McManus, Statements of Resolve, 11.

$9 \quad$ Paul K. Huth and Bruce Russett, "Deterrence Failure and Crisis Escalation," International Studies Quarterly 32, no. 1 (1988): 29-45.

10 Samuel S. G. Wu, "To Attack or Not to Attack: A Theory and Empirical Assessment of Extended Immediate Deterrence," Journal of Conflict Resolution 34 (1990): 531-52.

11 Danilovic, When the Stakes Are High.
} 
stake due to alliance ties and other possible arrangements. Nevertheless, nuclear weapons can dramatically change the dynamics of policy choice after deterrence failure due to their excessively destructive power.

\section{2. Impact of nuclear weapons after deterrence failure}

There are two competing views in the literature on the significance of nuclear weapons for the stability of deterrence posture: Nuclear Revolutionists (hereafter Revolutionists) ${ }^{12}$ and Nuclear Pessimists (henceforth Pessimists). ${ }^{13}$ The Revolutionists argue that due to their enormous destructive power, nuclear weapons have made military victory impossible. ${ }^{14} \mathrm{~A}$ minor military skirmish could escalate to nuclear war when crisis actors possess atomic weapons. Even a minimal number of nuclear penetrations should cause sufficient damage to the side that absorbs the strike. ${ }^{15}$ This dreadful image of nuclear war will surely dissuade crisis actors from making a violent move or having an illusion of victory in war. ${ }^{16}$ The "crystal ball"17 effect of nuclear weapons revolutionizes policymakers' strategic calculations, and nuclear weapons shall promote peace. ${ }^{18}$

Surprisingly, however, many studies find falsifying evidence to the Revolutionist prediction. ${ }^{19}$ Statistical evidence shows that the impact of nuclear weapons capability is not statistically significant, ${ }^{20}$ or fails to discourage crisis escalation. ${ }^{21}$ American deterrence has failed despite its advanced nuclear capability, ${ }^{22}$ and its weapons did not have a consistent impact on deterring the Soviet Union or China. ${ }^{23}$ One possible explanation for these puzzling trends is that most studies cover extended deterrence cases, which inherently struggle to succeed. However, those cases of the 1969 Sino-Soviet Border Dispute, the 1973 Yom Kippur War, the 1982 Falklands War, and the 1999 Kargil War reveal that even nuclear powers' attempts to protect their people and territories have failed often.

The Pessimists provide interesting explanations for these anomalies. First, according to Snyder's famous logic of "strategic stability-tactical instability,"24 "each side's nuclear weapons cancel out the influence of the other's"25 under Mutually Assured Destruction

12 Bernard Brodie et al., The Absolute Weapon (New York: Harcourt, Brace, 1946); Thomas C. Schelling, Arms and Influence (New Haven: Yale University Press, 1966); Robert Jervis, The Meaning of the Nuclear Revolution (New York: Cornell University Press, 1989); Rober Powell, Nuclear Deterrence Theory: The Search for Credibility (Cambridge: Cambridge University Press, 1990); Kenneth N. Waltz, "More May Be Better," in The Spread of Nuclear Weapons: a Debate Renewed, ed. Scott D. Sagan and Kenneth N. Waltz (New York: W.W. Norton \& Company, 2003), 3-45.

13 William L. Border, There Will Be No Time (New York: Macmillan, 1946); Paul Nitze, “Atoms, Strategy and Policy,” Foreign Affairs 34, no. 2 (1956): 187-88; Colin Gray, Nuclear Strategy and National Style (Lanham: Hamilton Press, 1986).

14 They can effectively destroy the "social and industrial heart of the enemy, so producing internal collapse and obviating the need for a traditional battlefield victory." Lawrence Freedman, Deterrence (Cambridge: Polity Press, 2004), 3. A small nuclear warhead (20-kiloton) is estimated to have 10,000 times more destructive power than a 1-ton conventional explosive. The damage will increase tenfold if dropped in densely populated cities. Steve Fetter, "Ballistic Missiles and Weapons of Mass Destruction: What Is the Threat? What Should be Done?" International Security 16, no. 1 (1991): 5-41.

15 Robert A. Pape, Bombing to Win: Air Power and Coercion in War (Ithaca: Cornell University Press, 1996$), 36$.

16 Geoffrey Blainey, The Causes of War (New York: Free Press, 1988).

17 Albert Carnesale et al., Living with Nuclear Weapons (New York: Bantam Books, 1983), 44; Jervis, The Meaning of the Nuclear Revolution, 7-8; Kenneth N. Waltz, "Waltz Responds to Sagan," in Sagan and Waltz, The Spread of Nuclear Weapons, $114-15$.

18 Jervis, The Meaning of the Nuclear Revolution, 23-38.

19 Harvey provides an excellent summary of these empirical findings. Harvey, The Future's Back, 22-32.

20 Huth and Russett, "What Makes Deterrence Work?"; Huth and Russett, "Deterrence Failure and Crisis Escalation."

21 Daniel S. Geller, "Nuclear Weapons, Deterrence, and Crisis Escalation," Journal of Conflict Resolution 34, no. 2 (1990): 291-310.

22 George and Smoke, Deterrence in American Foreign Policy.

23 Richard K. Betts, Nuclear Blackmail and Nuclear Balance (Washington: Brookings Institution, 1987).

24 Glenn H. Snyder, "The Balance of Power and the Balance of Terror," in Paul Seabury ed., The Balance of Power (San Francisco: Chandler, 1965): 184-201.

25 Jervis, The Meaning of the Nuclear Revolution, 20. 
(MAD). As it becomes almost nonsensical to fight with the high-level violence of a nuclear strike, crisis actors might believe it is safer and more feasible to turn to lower levels of assault.

Second, if it is a non-MAD situation, the logic of "preventive war" could encourage a superior nuclear power to destroy a much weaker nuclear adversary that lacks second-strike capability. ${ }^{26}$ Nevertheless, a preventive attack is most likely to involve surgical strikes against the opponent's nuclear facilities, which would make the balance of conventional forces matter more than that of nuclear weapons. ${ }^{27}$ Thus, nuclear weapons are often redundant under non-MAD conditions. ${ }^{28}$

Third, nuclear powers would be "self-deterred" from punishing the adversary due to the enormous economic, political, and normative costs they must pay. ${ }^{29}$ The weapons' destructive power is excessive, killing both combatants and non-combatants disproportionally, and nuclear punishment easily violates important international norms such as the UN Charter and the Nuremberg principles. ${ }^{30}$ Subsequently, the weapons' actual use could bring about political isolation from the international community, domestic backlash, loss of foreign investments, a coalition of balancing force, or even nuclear attacks by others. ${ }^{31}$

A recent study finds that American policymakers were reluctant to use nuclear weapons for punishing their adversaries through the analysis of the U.S. political-military wargames from 1958 to 1972. The key rationale supporting this choice was the adversary's second-strike capability, lack of tactical necessity to use the weapons, and fear of setting the precedent of using atomic weapons. ${ }^{32}$ In other words, sanctioning the challenger with nuclear weapons is unlikely until the defender successfully turns to these weapons as a feasible punishment tool. If this Pessimist theory were applied to the case at hand, it is highly probable that the original cause for the general deterrence failure - that is, Soviet defiance of the U.S. deterrent threat to avoid transforming Cuba into its forward military base- was the inherent low credibility of punishment with nuclear weapons.

If the Pessimist approach can predict Moscow's rationale undergirding its move to deploy middle-range nuclear missiles in Cuba, will this theory continue to be relevant in explaining Washington's reaction during the Cuban Missile Crisis? Given that the crisis broke out under the MAD context between the U.S. and the Soviet Union, policymakers in Washington might have pursued a violent punishment path anticipating non-nuclear retaliation by the USSR, as the Pessimists suggest. Nevertheless, it is plausible that the "crystal ball" effect ultimately led some cooler-headed security advisors to forgo recommending escalatory measures. The next section advances a hypothesis and its competing counterpart to test the relevance of the Revolutionist and Pessimist theories in explaining moves made by the U.S. during the Cuban Missile Crisis.

\footnotetext{
26 Scott D. Sagan, "More Will Be Worse," in Sagan and Waltz, The Spread of Nuclear Weapons, 46-88.

27 Lyle J. Goldstein, Preventive Attack and Weapons of Mass Destruction: A Comparative Historical Analysis (Stanford: Stanford University Press).

28 Todd S. Sechser and Mathew Fuhrmann, Nuclear Weapons and Coercive Diplomacy (Cambridge: Cambridge University Press, 2017), 47-8.

29 Nina Tannenwald, "Stigmatizing the Bomb: Origins of the Nuclear Taboo," International Security 29, no. 4 (2005): 5-49; T.V. Paul, "Self-Deterrence: Nuclear Weapons and the Enduring Credibility Challenge," Canada 's Journal of Global Policy Analysis 71, no. 1 (2016): 20-40; Sechser and Fuhrmann, Nuclear Weapons and Coercive Diplomacy.

30 T.V. Paul, "Self-Deterrence," 33-9.

31 Sechser and Fuhrmann, Nuclear Weapons and Coercive Diplomacy, 48-50.

32 Reid B.C. Pauly, "Would U.S. Leaders Push the Button? Wargames and the Sources of Nuclear Restraint," International Security 43, no. 2 (Fall 2018): 151-92.
} 


\subsection{Research hypothesis and its competing counterpart: The infeasibility of nuclear retaliation}

The dependent variable of this study is the policy choice available to a defender after the failure of direct-general deterrence: (1) rapid escalation, (2) hedging, (3) gradual escalation, and (4) de-escalation. First, rapid escalation indicates that the defender decides to use actual force to respond to the general deterrence failure. Second, hedging means the defender's use of military force in a non-violent way to employ it as a bargaining chip. Third, gradual escalation implies its use of non-military measures. Fourth, de-escalation implies that the defender directly opts for a non-action course, surrendering what it possessed before the crisis' outbreak.

This study's independent variable is the feasibility of nuclear weapons retaliation. The ultimate infeasibility of implementing nuclear punishment makes American nuclear deterrence non-credible in the eyes of the Soviets. Washington also would not believe that Moscow would turn to nuclear retaliation if U.S. punishments stay below the threshold of using nuclear weapons. Thus, the Pessimist hypothesis posits that Washington D.C.'s policy circle should be open to violent military measures such as airstrikes and invasion.

The logic explained above would only change if the USSR were to successfully address the weapons' inherent infeasibility problem. The following two cases would meet this condition. First, Moscow secures full power projection capability to deliver the weapons. Second, American forces destroy or are about to destroy densely populated cities in the Soviet Union or Cuba, providing political justification to respond with nuclear riposte. Hence, the Soviet feasibility of nuclear retaliation is a function of Moscow's military feasibility to implement nuclear retaliation and the degree of aggressiveness in American policy choices. The rival hypothesis is the Revolutionist approach: mere possession of nuclear weapons, not the feasibility of their use, should make Americans refrain from taking violent measures.

Research Hypothesis: If nuclear retaliation appears infeasible to the USSR, the U.S. will consider military options.

Rival Hypothesis: If the Soviet Union possesses nuclear weapons (regardless of the type of nuclear balance), the U.S. will avoid punishing the defiance violently.

\section{Case Study: The Cuban Missile Crisis}

\section{1. Case selection and methodology}

This article tests research and rival hypotheses against the Cuban Missile Crisis. It is a remarkably rare case in which humanity may have been on the brink of a nuclear holocaust and the possibility of mass extinction. Thus, this case provides researchers with an exceptional laboratory for testing various hypotheses on crisis escalation and de-escalation as well as deterrence and compellence involving nuclear threats. President John F. Kennedy contributed to the elevation of this crisis's academic significance even further by recording almost all of the Executive Committee of the National Security Council (ExComm) meetings that took place during the portentous thirteen days. The availability of the Kennedy Tapes allows scholars to open the black box and analyze the decision-making process of the crisis actors at the critical juncture. This study tests the set of research and competing hypotheses proposed in the previous section against the American policymaking dynamic during the crisis. The article investigates declassified primary sources, the Kennedy Tapes, and memoirs 
of the political elites in Moscow and Washington.

It is a single case study with a limited number of observations. This is a methodological inconvenience recognized at the outset of the study in order to work around it and use the case effectively. Of course, it is recognized that to test the impact of the independent variables on the dependent variable, the study needs multiple observations that would produce variations on the dependent variable. In an ideal methodological condition, this would allow the study to engage in a controlled comparison. The unavailability of multiple observations makes the single case study approach a weak design of the research. ${ }^{33}$

The study generates multiple observations within a single case study by disaggregating the data to address this shortcoming. ${ }^{34}$ Consequently, this study develops more observable implications of the theory expounded above by running process-tracing on key individuals who integrated the various political elites within the ExComm over different phases of the thirteen-day crisis. Accordingly, every single individual who participated in each ExComm meeting constitutes an empirical observation. By treating the data as such, this article aims to conduct a "most similar system" comparison, analyzing the same actors at different intervals throughout the tense crisis. ${ }^{35}$

This research traces the deliberation process throughout the ExComm meetings from the point when Washington discovered the presence of Soviet missiles in Cuba on October 15 and convened the first ExComm meeting the next day to the moment when Kennedy decided to take the naval blockade option on October 20. The analysis compares divergent perspectives within the ExComm. It attempts to demonstrate how different individual perspectives about the USSR's feasibility of nuclear retaliation led policymakers in Washington to decide on different countermeasures against the Soviet challenge to the U.S. deterrent threat. Specifically, the focus of the analysis is on the following five individuals as separate within-cases in this study as they represent the final two approaches - "airstrike" vs. "blockade"- that emerged at the National Security Council (NSC) meeting on October 2036: First, McGeorge Bundy, Special Assistant to the President for National Security Affairs, second, General Maxwell Taylor, Chair of the Joint Chiefs of Staff, third, Dean Rusk, Secretary of State, fourth, Robert McNamara, Secretary of Defense, and, fifth, President John. F. Kennedy. ${ }^{37}$ The following analysis is based on the transcription of tape recordings of the ExComm meeting ${ }^{38}$ and the minutes of the $505^{\text {th }}$ NSC meeting..$^{39}$

33 Many recent studies on qualitative methodology disagree with this argument. Their arguments are mainly based on: (1) difference between causal-process observations (CPOs) and data-set observations (DSOs); (2) importance of studying deviant cases; and (3) usefulness of with-in case studies. Henry E. Brady, "Data-Set Observations versus Causal-Process Observations: the 2000 U.S. Presidential Election," in Rethinking Social Inquiry: Diverse Tools, Shared Standards, ed. Henry E. Brady and David Collier (Rowman \& Littlefield Publishers, 2010), 237-42; and David A. Freedman, "On Types of Scientific Inquiry: The Role of Qualitative Reasoning," in Rethinking Social Inquiry, 221-36; and Alexander George and Andrew Bennett, Case Studies and Theory Development in the Social Sciences (Boston: MIT Press, 2005).

${ }_{34}$ Gary King, Robert O. Keohane, Sidney Verba, Designing Social Inquiry: Scientific Inference in Qualitative Research (Princeton, N.J.: Princeton University Press, 1994), 48.

35 George and Bennett, Case Studies and Theory Development in the Social Sciences, 81.

36 The first two supported the "airstrike alternative" and the other two suggested the "blockade route." Ernest R. May and Philip D. Zelikow, The Kennedy Tapes: Inside the White House during the Cuban Missile Crisis (Cambridge, Mass: Belknap Press of Harvard University Press, 1997): 193-5. May and Zelikow break down these two groups into four perspectives that include: (1) airstrike (by Special Assistant Bundy and Chairman of JCS General Taylor and), (2) blockade as an ultimatum (by Secretary Dillon, Attorney General Robert Kennedy, and CIA Director McCone), (3) blockade as deterrence or freezing the Soviet action (by Secretary Rusk), and (4) blockade as an opening of negotiation (by Secretary McNamara, Ambassador Stevenson, and Special Counsel Sorensen). May and Zelikow, The Kennedy Tapes, 191.

${ }_{37}$ Kennedy, in the following passages, refers to the President, not his brother, Robert Kennedy, who also participated in the ExComm meetings as Attorney General.

${ }_{38}$ For the transcript of the Kennedy's tape recordings, this study uses Presidential Recordings Digital Edition published by the Rotunda and the Miller Center.

39 Foreign Relations of the United States (FRUS), 1961-1963, Volume XI: Cuban Missile Crisis and Aftermath (Washington D.C.: United States Government Printing Office, 1996), 126-36. 


\section{2. Kennedy's deterrent threats in September 1962}

Before starting to analyze the ExComm meetings, it is important to check whether the U.S. made a clear deterrent threat before the crisis. Starting in August 1962, a series of reports arrived in Washington about a significant increase in the number of commercial ships sailing towards Cuba. ${ }^{40}$ CIA Director John McCone believed that the astonishing boost of Soviet shipments to Cuba might be the harbinger of his worst nightmare: turning the island less than 100 miles away from the U.S. into a Soviet missile base. He feared that Khrushchev would always be tempted to deploy medium-range nuclear missiles in Cuba to even the scales of nuclear balance significantly favoring the U.S. McCone first raised this possibility during the Special Group meeting on August 10, 1962, and called for the use of the U.S. military force only to be rejected by the majority of security advisors. ${ }^{41}$

The U-2 flight over Cuba on August 29 found that eight Surface-to-Air Missile (SAM) sites were only one or two weeks from completion, and that there had been a significant increase in defense capability compared to what the previous reconnaissance flight found on August 5. However, instead of following McCone's proposal, Kennedy decided to give a fair warning to Khrushchev. On September 4, the White House Press Secretary Pierre Salinger read the presidential statement that the U.S. was aware of Soviet technicians and USSR weapons such as antiaircraft defense missiles and motor torpedo boats in Cuba. Washington confirmed that they had not found "any organized combat force in Cuba from any Sovietbloc country; of military bases provided to Russia; of a violation of the 1934 treaty relating to Guantanamo; of the presence of offensive ground-to-ground missiles; or other significant offensive capability." However, the statement added, "[w]ere it to be otherwise, the gravest issues would arise." ${ }^{\prime 2}$ Kennedy reiterated this warning on September 13, 1962, during the presidential news conference.

\footnotetext{
If at any time the Communist buildup in Cuba were to endanger, or interfere with our security in any way, including our base at Guantanamo, our passage to the Panama Canal, our missile and space activities at Cape Canaveral, or the lives of American citizens in this country, or if Cuba should ever attempt to export its aggressive purposes by force or the threat of force against any nation in this hemisphere, or become an offensive military base ${ }^{43}$ of significant capacity for the Soviet Union, then this country will do whatever must be done to protect its own security and that of its allies [emphasis added]. ${ }^{44}$
}

The Kennedy administration's warnings on September 4 and 13 confirm that the Missile Crisis was a case of deterrence failure. Yet, it could also be labeled as a compellence failure because, before Kennedy made those threats, Khrushchev had already ordered the implementation of Operation Anadyr and done things described in Kennedy's list of don'ts. These actions included authorizing deployments of two R-14 IRBMs regiments, three R-12 MRBMs regiments, thirty-three IL-28 bombers, thirty-three Mi-4 helicopters, forty MiG$21 \mathrm{~s}$, and four Motorized Rifle Regiments. ${ }^{45}$ The first ship carrying SAMs and supporting

\footnotetext{
40 Fursenko and Naftali, One Hell of a Gamble, 198-99; Khrushchev, Nikita Khrushchev and the Creation of a Superpower, $511-12$.

${ }^{41}$ Fursenko and Naftali, One Hell of a Gamble, 199-204.

42 Mark J. White, The Kennedys and Cuba: The Declassified Documentary History (Chicago: Ivan R. Dee, 1999), 151.

43 When asked by a journalist, Kennedy defined the "offensive force," as "a capability to carry out offensive actions against the United States." Ibid., 156

44 Ibid., 155.

45 "List of Troops and Commanders to take part in Operation 'Anadyr'," June 20, 1962, History and Public Policy Program Digital Archive, Library of Congress, Manuscript Division, Dmitriĩ Antonovich Volkogonov papers, 1887-1995, mm97083838, reprinted in Cold War International History Project Bulletin 11. Translated by Raymond Garthoff. https://digitalarchive.wilsoncenter.
} 
apparatus for the MRBMs left the Soviet port at the end of July, ${ }^{46}$ and the first shipment, the Maria Ulyanova, arrived in Cuba on July $26 .{ }^{47}$ In this regard, Kennedy's threats in September 1962 can be identified as a compellent threat in the eyes of Moscow.

However, the main element of Soviet forces that Kennedy was most worried about had not arrived in Cuba when he made his September threats. The first Soviet MRBMs arrived on September 15. It was two days after the announcement of Kennedy's second threat and eleven days after his first warning. ${ }^{48}$ This fact, thus, still makes the crisis a general deterrence failure. Besides, Washington was not aware of Khrushchev's decision in June and responded to the crisis as if the U.S. general deterrent threat had failed. Therefore, after detecting the failure, the deliberation should be treated as an example of the strategic thinking process after general deterrence failure because the defender believed that it was such. Thus, those complications related to the true nature of the failure would not pose a severe challenge to this research's validity.

\section{3. The first ExComm Meeting on October 16, 11:40 AM - 1:00 PM}

This first ExComm meeting started with the report by CIA Assistant Director of Photographic Interpretation Arthur Lundahl and Chief of the Missile and Space Division Sydney Graybeal. They summarized what the CIA had found from the photos taken during the October $14 \mathrm{U}-2$ flight over Cuba: one MRBM launch site and two newly-established military encampments in west-central Cuba. However, many uncertainties put the committee in a challenging position in devising countermeasures. For example, Washington did not know: (1) how many other missile sites might have been under construction on different parts of the island; (2) when these other missiles would be operational; (3) whether the missiles had nuclear warheads or, if not, where they were stored; and, critically, (4) what the intention of the Soviets was. ${ }^{49}$ In other words, while it seemed clear that Khrushchev blatantly challenged Kennedy's deterrent posture, the exact degree and depth of the violation was uncertain.

Secretary Rusk was the first advisor to suggest possible countermeasures. First, he defined the missile deployment in Cuba as a "very serious development," which the U.S. should eliminate. Secretary Rusk then proposed two general courses of action: (1) a surprise attack, but not necessarily an invasion of Cuba, and (2) a combination of non-violent measures that could make Moscow give up the missile bases..$^{50}$ Although he was open to both paths (rapid and gradual escalations), Rusk preferred the second option. For him, the U.S. was facing "a situation that could well lead to general war," and it would be essential to give "everybody a chance to pull away from it before it gets too hard." ${ }^{51}$

\footnotetext{
org/document/113050.

46 Bruce J. Allyn, James G. Blight and David A. Welch, "Essence of Revision: Moscow, Havana, and the Cuban Missile Crisis," International Security 14, no. 3 (1989-1990): 149.

47 Taubman, Khrushchev, 550.

48 Allyn, Blight and Welch, "Essence of Revision," 152.

49 Don Munton and David A. Welch, The Cuban Missile Crisis: A Concise History (New York: Oxford University Press, 2012), 51 .

50 The measures include: (1) stimulating the OAS procedure and operate through an OAS inspection team; (2) sending a message to Castro to warn him that Khrushchev would trade Cuba for Berlin; (3) calling up highly selected units less than 150,000 for emergency and reinforcing forces in Guantanamo; (4) creating confusion in Cuba using anti-Castro guerrilla groups; (5) alerting other allies; and (6) calling in General Eisenhower. May and Zelikow, The Kennedy Tapes, 54-7.

${ }_{51}$ "Meeting on the Cuban Missile Crisis on 16 October, 1962," Tape 28, John F. Kennedy Library, President's Office Files, Presidential Recordings Collection, Presidential Recordings Digital Edition [The Great Crises, vol. 2, ed. Timothy Naftali and Philip Zelikow] (Charlottesville: University of Virginia Press, 2014-). URL: http://prde.upress.virginia.edu/conversations/8020044 (accessed on July 17, 2020). All direct quotes in this section are from this source.
} 
In response, Secretary McNamara tried to set a principle that any type of airstrike would only be feasible if those Soviet missiles in Cuba were not operational. Furthermore, he argued that if the final course of action were to involve a military measure, it should be either an invasion of Cuba or an extensive strike that could wipe out all related offensive assets (i.e., the missile sites, aircraft, airfields, and potential nuclear storage sites). Before the meeting was over, McNamara emphasized that they should decide on three separate issues: (1) whether Washington should inform the public about the discovery of offensive nuclear weapons in Cuba; (2) whether the U.S. should conduct military action in tandem with a political measure; and (3) how much time should be allocated to prepare for effective military action. Indeed, similar to Rusk, he was open to both political and military measures, but McNamara's perspective (conditional rapid-escalation) was the most cautious one among all the ExComm members as he strictly set a precondition for the airstrike option: only before the missiles became operational.

General Taylor agreed with McNamara on the need to take out all the missiles once the U.S. Air Force went into Cuba. However, he was pessimistic about the possibility of knowing the exact timing of when those missiles would be operational. This uncertainty made General Taylor suggest that the U.S. should get "all the benefit of surprise" and destroy all the offensive weapons, including missiles, airfields, and nuclear sites, as soon as Washington acquired sufficient information on the locations of those targets. Simultaneously, the implementation of two more measures was suggested: (1) a naval blockade for the sake of preventing further deployment of Soviet missiles to the island, and (2) reinforcement of the Guantanamo naval base and evacuation of dependents from the garrison. Whether an invasion was necessary or not could be determined after this, he argued. His idea was the most aggressive approach (rapid escalation) within the ExComm.

Special Assistant Bundy's position was not clearly defined in this first meeting. He pointed out that a surgical strike should not be ruled out because of the "substantial political advantage in limiting the strike." However, Special Assistant Bundy also demonstrated his interest in a non-violent track toward resolution. When Kennedy summarized his staffs' positions into three alternatives - an immediate surgical strike, a general airstrike, and the invasion-, Bundy added that the committee needed to work out a contingency on the political measures as well.

In sum, although all ExComm members were open to some types of military responses, except for Taylor, the rest were cautious about going directly to a military punishment such as an airstrike (either surgical or extensive) or an invasion. They also revealed the varying degree of circumspection: the most reluctant among the three was McNamara, possibly the least hesitant was Bundy, and in between them was Rusk. President Kennedy did express that the U.S. was "certainly going to do [option] number one. We're going to take out these missiles" in the end and emphasized the importance of preparing for it. Nonetheless, he preferred to listen to his advisors' suggestions rather than push his stance during this meeting.

\section{4. The second ExComm Meeting on October 16, 6:30 PM - 7:55 PM}

When the ExComm meeting convened at 6:30 PM again on the same day, General Marshall Carter, Deputy Director of Central Intelligence, brought additional information to the committee based on further readout of photographic evidence reported in the morning. First, there may be sixteen to twenty-four missiles in Cuba. Second, these missiles were likely 
the solid-propellant type with an inertial guidance system, which would take about two weeks to be ready, yet could be fired on short notice once they became operational. Third, these missiles were highly vulnerable even to ordinary rifle fire. Fourth, the reconnaissance flight did not find any evidence of nuclear warhead storage. Fifth, they verified again that those missiles were MRBMs that matched the information provided by "IRONBARK." 52 These reports revealed that the USSR flagrantly challenged the U.S. deterrent threat but that American conventional weapons could quickly take out those Soviet missile facilities.

Since the missiles did not appear operational, McNamara backed the airstrike. He opposed any attack that could leave out some nuclear capabilities - missiles, MiG aircraft, airfields, nuclear storage facilities, radar installations, and SAM sites - on the island and specified that the Joint Chiefs of Staff (JCS) unanimously supported this military option. McNamara explained that the extensive airstrike would require around 700 sorties a day, but that the U.S. Air Force and Navy could conduct the massive strike operation well beyond this level. Taylor concurred with him and claimed that it would be a mistake to take any limited version of the strike as it would attract reprisal attacks. He argued that there might not be a second chance once the U.S. attacked those bases. Taylor underscored that JCS's position was that Washington would rather take no military action at all than to go with a limited strike. ${ }^{53}$

From his vantage point, Rusk raised the issue of rendering warning, including a compellent threat to Cuba, before the attack. He shared a couple of measures suggested by his people in the State Department, namely (1) sending a direct warning message to Castro; (2) indicating the imminent danger rising from Cuba to states in Latin America that were vulnerable to communist revolutionary actions (i.e., Venezuela, Guatemala, Bolivia, Chile, and Mexico); and (3) letting close allies in Europe know about the situation. However, this did not mean that his position tilted to the political course of action. Rusk implied that the committee should discuss "what political preparation, if any, is to occur before an airstrike or in connection with any military action."

McNamara opposed this political course of action because "it almost stops subsequent military action." He was open only to an intermediate route that included concurrent execution of a declaration of open surveillance, a blockade, and preparation to attack the Soviet Union immediately. Taylor agreed with McNamara and emphasized that he "can't visualize doing it [an air attack] successfully that way [announcing the attack]" as the missiles were the movable type that could quickly disappear into the forest. Although preferring a limited strike, Bundy also aligned with McNamara on the surprise attack idea.

When the majority was suggesting a massive strike, President Kennedy set forth his view from here. He agreed that Washington should do something because he warned Khrushchev twice not to deploy any offensive weapons in Cuba and "when we said we're not going to, and then they go ahead and do it, and then we do nothing, then I would think that our risks increase." But his position was different from that of others on two grounds.

First, Kennedy was very reluctant to eliminate the limited strike option as the crisis was

52 May and Zelikow, The Kennedy Tapes, 78-82. IRONBARK was a code name for Colonel Oleg Penkosvsky, a Soviet military intelligence officer, who provided information on Soviet nuclear capabilities to the U.S. He was exposed and arrested on October 22, 1962, later executed.

53 “Meeting on the Cuban Missile Crisis on 16 October, 1962," Tapes 28 and 28A, John F. Kennedy Library, President's Office Files, Presidential Recordings Collection, Presidential Recordings Digital Edition [The Great Crises, vol. 2, ed. Timothy Naftali and Philip Zelikow] (Charlottesville: University of Virginia Press, 2014-). URL: http://prde.upress.virginia.edu/conversations/8020045 (accessed on July 17, 2020). All direct quotes in this section are from this source. 
"a political struggle as much as military." Efforts to destroy too-extensive targets were not very different from invasion and would significantly increase "the dangers of the worldwide effects." In this regard, the selective strike was much more "defensible [and] explicable, politically, or satisfactory in every way." Bundy wholeheartedly agreed on this and said the political advantage of the surgical strike was substantial as it corresponded to "the punishment fits the crime" - "we are doing only what we warned repeatedly and publicly we would have to do."

Second, even though he acknowledged that public warning before the attack would "lose all the advantages of our strike," Kennedy wanted to discuss further the way to inform NATO allies and fragile governments in Latin America. He wished to make a public statement due to the political merits of expressing Washington's "desire to restrain." Rusk responded that a combined course of action - the limited strike, plus sending messages to Khrushchev and Castro-was feasible. The reason was that the move to take out the offensive assets was "none other than simply the fulfilling of the statements" that Kennedy made earlier.

To sum up, almost every participant in the second meeting, except for President Kennedy, leaned towards the rapid escalation path. This increase of aggressiveness in the American policy choice was because it turned out that while the level of the Soviets' challenge (sixteen to twenty-four MRBMs under construction) was severe, it seemed entirely feasible for the U.S. to take out those missile bases. They were not operational yet and very vulnerable.

\subsection{The third ExComm Meeting on October 18, 11:10 AM - 1:15 PM}

On October 17, President Kennedy resumed his regular schedule to avoid possible suspicions by Moscow. He met the West German foreign minister, attended a luncheon for the Libyan Crown Prince, and flew to Connecticut to support the campaign of a Democratic candidate running for the U.S. Senate. Meanwhile, his staff continued to meet and discuss possible countermeasures against the Soviet challenge. CIA Director John McCone returned from his stepson's funeral and joined the team. The JCS came up with five different groups of targets with required numbers of sorties: (1) Target I-missiles and nuclear storages (52 sorties); (2) Target II-Target I plus IL-28s and MiG-21s (104 sorties); (3) Target III-Target II plus other aircraft, SAM sites, cruise missiles, and missile boats (194 sorties); (4) Target IV - all military targets except for tanks (474 sorties); and (5) Target V-all military targets (2,002 sorties). Key agendas for the ExComm meeting on October 17 were, first, which type of military action Washington should take; and second, whether political measures were to precede before the attack. Kennedy returned from his campaign trip on Wednesday night but decided to stay out of the discussion until the next day. The meeting went on until midnight. ${ }^{54}$

The next morning, McCone informed the president of new findings from complete readouts of images taken by U-2 flights over Cuba on October 14 and 15 as well as from additional photographs taken on October 17. First, the reconnaissance mission discovered two more missile sites to the southwest of Havana that showed the pattern of a MRBM/IRBM launch complex. Second, the three missile bases discovered earlier seemed to have expedited the development. Sixteen to twenty-four missiles were now to be operational within a week. Third, two more cruise-missile sites were found at Santa Cruz del Norte. Fourth, the photo images revealed an airfield for IL-28s at San Julian. ${ }^{55}$ These intelligence updates revealed

54 May and Zelikow, The Kennedy Tapes, 119-21.

55 "Meeting on the Cuban Missile Crisis on 18 October, 1962," Tapes 30 and 30A, John F. Kennedy Library, President's Office 
that the situation was much more dangerous than the ExComm members had first thought, specifically because of the IRBMs that placed ninety-percent of the American population in jeopardy..$^{56}$

It turned out that the Soviets had made an extremely dangerous move, and most ExComm members, including Rusk, McNamara, Taylor, and Kennedy, ruled out the non-action option. Rusk warned that backing down from the clear warning of the head of state would inevitably "free their [Soviets] hands for almost any kind of intervention," possibly in Berlin and Korea. He also feared that non-action should "undermine and undercut the long support [from the public] that we need." He recommended that Washington take massive military action with the legal basis of the Rio Pact or by the declaration of war on Cuba. Rusk emphasized that a surgical strike would involve "the greatest risks" because it was to aim at destroying a too-high number of targets. Nevertheless, he continued to share a more prudent voice in his department, especially the note ${ }^{57}$ of Charles Bohlen, former Ambassador to the Soviet Union, who asserted the necessity of taking diplomatic actions before turning to any military measure.

McNamara sided with Rusk and underscored the need to remove any limited strike option, aiming to destroy only Targets I or II, from the table. The new intelligence indicated that the U.S. should at least destroy Target III. Leaving any Soviet nuclear capability behind would pose an enormous risk to the Guantanamo naval base and the eastern coast of the States after the airstrike on Soviet MRBMs in Cuba. However, he did not believe that a twenty-four-hour warning before the military action would adversely affect the success of the strike operation.

Taylor also agreed with Rusk and McNamara on the necessity of an extensive strike. However, he disagreed on the impact of warning before the attack. He reminded the committee members of the great vigor and swift progress in the developing Soviet offensive capabilities on the island, and that time was not on the Americans' side. Considering the vulnerable air defense system in the southern part of the States, Washington needed to destroy IL-28s. Unfortunately, the new intelligence report showed that these jet bombers were in ideal and well-protected airfields. U.S. forces, thus, should wipe out the SAM sites before attacking those airbases. Also, IRBMs would turn the island into a powerful forward base of the Soviet Union. He was very skeptical about the merit of diplomatic action as it would never stop the Soviets from building up their capability. All the Soviet offensive missiles and IL-28s should be smashed with a massive surprise attack as soon as possible. This idea of a massive surprise attack, however, was not welcomed by others. Llewellyn Thompson, ambassador to the Soviet Union, argued that it would kill a lot of Russians, which should arouse a public reaction in Moscow. Under Secretary of State George Ball compared it with the Japanese attack on Pearl Harbor and said: "It is not conduct that one expects of the United States."

President Kennedy agreed that the U.S. should take some measures to punish Khrushchev for his flagrant challenge against American deterrent threats. Still, those actions should be conducive to lessening "the chances of a nuclear exchange" and maintaining "some degree

Files, Presidential Recordings Collection, Presidential Recordings Digital Edition [The Great Crises, vol. 2, ed. Timothy Naftali and Philip Zelikow] (Charlottesville: University of Virginia Press, 2014-). URL: http://prde.upress.virginia.edu/conversations/8020048 (accessed on July 17, 2020). All direct quotes in this section are from this source.

56 Munton and Welch, The Cuban Missile Crisis, 54.

7 Bohlen's major concerns over a strike without warning were threefold: the strike (1) would immediately lead to war; (2) might disunite the U.S. allies as the Soviet would choose to retaliate indirectly such as against Turkey, Italy, or Berlin; and (3) would be very difficult to be justified without the proper declaration of war. "Meeting on the Cuban Missile Crisis on 18 October, 1962 ," Presidential Recordings Digital Edition. 
of solidarity with our allies." The unannounced attack, in this regard, was too risky. In the same vein, he was reluctant to declare war on Cuba, even if it was merely for providing a legal ground for the blockade, as the term gave an impression that the U.S. objective was an invasion. In contrast, warning Khrushchev might not only lead to minimizing the Russian causalities but also to Moscow's backing down. Based on these arguments, Kennedy laid out a prospective course of action that included an announcement about the U.S. discovery of the Soviet missiles in Cuba and limited airstrike to take out only those missiles. He strictly went against the invasion. Instead, Kennedy suggested a possibility of trading missiles in Turkey with those in Cuba.

Bundy sided with the president and elaborated on the idea of a missile trade. Interestingly, he argued that this bargaining process could occur even if Washington made the "sudden strike." During the talk, Bundy said, it was necessary to give a message to Khrushchev stating that the U.S. could understand the Soviet rationale of building these missile bases in Cuba and Washington was open to trading the U.S. base in Turkey for Soviet missiles in Cuba. McCone opposed this trade idea, but Bundy replied that the crisis would eventually lead to the presence of Soviet submarines in the Caribbean, and this was "a political not a military problem."

Based on this discussion, McNamara outlined the two courses of action that Washington could take: (1) "slow introduction to military action" (or hedging) that included a political statement and blockade and (2) the "rapid introduction to military action" (or rapid escalation), a brief warning to Khrushchev followed by a forceful military attack. Except for Taylor, all the ExComm members believed that Washington should notify Moscow in some way before the U.S. military operation against the Soviet bases in Cuba. Before they closed the meeting, Theodore Sorensen, Kennedy's speechwriter, summarized the discussion by saying that there was a "general though not unanimous agreement" that "some kind of representation to Khrushchev ahead of time [before the military action]" was necessary.

\section{6. The fourth ExComm Meeting on October 20, 2:30 PM - 5:10 PM}

The meeting started with the intelligence report as usual. This time, CIA Deputy Director Ray Cline updated the council on missile developments in Cuba. He reported that among those four to five MRBM sites, two of them were believed to be in the state of "limited operational readiness." Also, the reconnaissance mission found two fixed IRBM sites under construction. One was estimated to be operational within six weeks, while the other would be between December 15 and 31. Although the U-2 flight did not find the nuclear warhead storage, the intelligence team supposed that these warheads should be nearby, given that the MRBMs and IRBMs would be "ineffective" without them. The report concluded with the estimation that around eight MRBMs were fully operational and ready to be fired..$^{58}$

The two courses of action that McNamara summarized in the previous ExComm meeting were developed into a Presidential message and a well-formulated scenario report. Because the intelligence report suggested that some of those Soviet nuclear missiles in Cuba were operational, McNamara switched his position from rapid escalation to "blockade route" (hedging). Rusk, McNamara, Stevenson (U.S. Ambassador to the UN), and Sorensen supported this path. Bundy, on the other hand, converted from gradual escalation to "airstrike

58 Mary S. McAuliffe, CIA Documents on the Cuban Missile Crisis (Darby: Diane Pub Co, 1995), 221-26; May and Zelikow, The Kennedy Tapes, 191-92. 
alternative" (rapid escalation) as he believed that a decisive action might lead to "a fait accompli" that would be difficult to be reversed by the Soviets. ${ }^{59}$ Taylor, C. Douglas Dillon (Secretary of the Treasury), and McCone endorsed this course of action.

Unfortunately, as the ExComm members convened in the Oval Office, we do not have the tape-recording transcripts for this meeting. Instead, we have the minutes for this NSC meeting that are "exceptionally detailed" and included "two-turn exchanges" (e.g., argument and counterargument; question and answer). ${ }^{60}$ However, they still lack "the intensity of exchanges" between the clashing approaches ${ }^{61}{ }^{1}$ This section, thus, briefly discusses the main argument of the two competing perspectives.

First, the "blockade route" was defined as a series of attempts to prevent the additional transfer of Soviet missiles to Cuba and to remove the already deployed offensive assets through negotiations (e.g., trading American missiles in Turkey or Italy with the Soviet ones in Cuba, limiting American use of Guantanamo). If Moscow responded with too-risky demands, the blockade could be followed by an ultimatum to remove the missiles backed by the punishment of an airstrike. McNamara knew it might take a long time to take out those missiles, and that it would damage the U.S.'s reputation, which would have some repercussions for domestic politics and alliance relations. This gradual escalation path, he believed, had at least four advantages: (1) causing less trouble to allies; (2) avoiding a surprise attack that would betray the American tradition; (3) taking the only possible military action that fit "the leader of the free world"; and (4) preventing escalation to a general war. ${ }^{62}$

The "airstrike alternative" was a path to destroy all the missiles and the jet bombers simultaneously. Those who supported this course of action had the following rationale. First, the very existence of those missiles could not be accepted, and the longer they remained stationed there, the riskier the situation would be. ${ }^{63}$ Second, this was the last chance for Washington to remove USSR offensive capability in Cuba because it would become impossible to locate them once the Soviets completed camouflaging the weapons. ${ }^{64}$ Third, even though some nuclear missiles might survive after receiving the extensive American airstrike, Moscow would not retaliate against Washington with the second-strike capability ${ }^{65}$

Figure 1 summarizes the shifting positions of the American policymakers throughout the first four ExComm meetings.

59 May and Zelikow, The Kennedy Tapes, 189.

60 David R. Gibson, Talk at the Brink: Deliberation and Decision during the Cuban Missile Crisis (Princeton: Princeton University Press, 2012), 99.

61 May and Zelikow, The Kennedy Tapes, 202.

62 FRUS 1961-1963, Vol. 11, 129.

63 Ibid., 132

64 Ibid., 129.

65 Ibid., 129. 


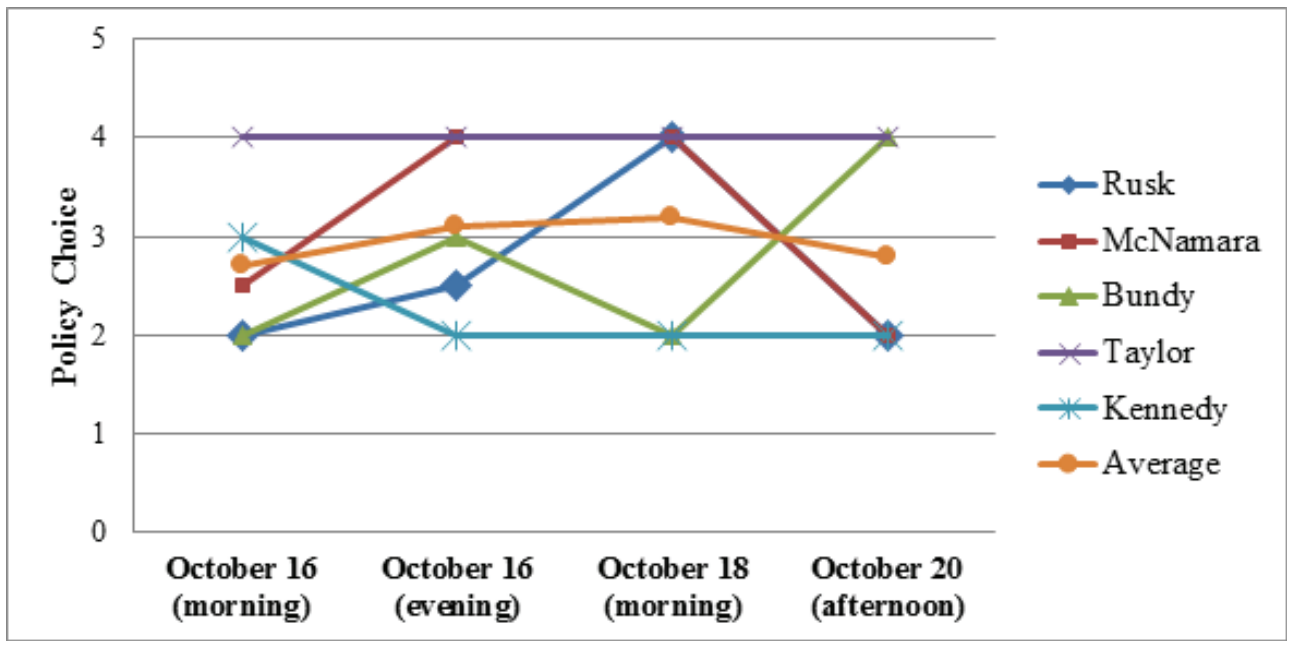

Figure 1: American Policymakers' Shifting Positions ${ }^{66}$

On average (the line with circle markers), the ExComm members urged more aggressive policies as they learned more about the nature of the Soviet challenge. However, they swiftly toned down their approach as soon as the intelligence team informed them that eight MRBMs had gotten ready to be fired. Both Rusk and McNamara followed quite a similar pattern of the average fluctuations within the ExComm, though McNamara showed a more extreme change of positions. Bundy demonstrated a somewhat divergent tendency in his policy recommendations as he abruptly changed his position from hedging to rapid escalation accompanying an unannounced extensive strike on Cuba. Kennedy and Taylor did not display much variation in their policy choices. But they asserted very stark positions: hedging with political inducements vs. rapid escalation turning to surprise air attack aiming at all Soviet assets on the island.

${ }_{66}$ The numbers in the y-axis are dummy variables indicating different degree of aggressiveness in their policy choice. "0" means "Non-action"; "1" indicates "Gradual Escalation"; "2" is "Hedging (Non-violent Use of Military Force plus Political Assurance)"; "3" implies "Unannounced Rapid Escalation but Limited in Scale"; "4" signifies "Unannounced Rapid Escalation Involving Extensive Strike"; and "5" denotes "Maximum Retaliation Including Nuclear Attack" 


\subsection{Explaining the origin of the American hedging: Testing research and rival hypotheses}

\section{Table 1- Summary of the Decision-making Process during the Cuban Missile Crisis}

\begin{tabular}{|c|c|c|c|c|c|c|}
\hline & \multirow[b]{2}{*}{ Actor } & \multirow{2}{*}{$\begin{array}{l}\text { U.S. } \\
\text { Credibility }\end{array}$} & \multicolumn{2}{|c|}{ Soviet Credibility } & \multicolumn{2}{|c|}{ Policy Recommendation } \\
\hline & & & $\begin{array}{l}\text { Military } \\
\text { Feasibility }\end{array}$ & $\begin{array}{l}\text { U.S. } \\
\text { Aggressiveness }\end{array}$ & Policy & Type \\
\hline 1 & Rusk1 & $\begin{array}{l}\text { No } \\
\text { mention }\end{array}$ & No mention & Undecided & $\begin{array}{l}\text { Unannounced Surgical Strike } \\
\text { or Warning }\end{array}$ & $\begin{array}{c}\text { Gradual } \\
\text { or Rapid } \\
\text { Escalation }\end{array}$ \\
\hline 2 & Rusk2 & $\begin{array}{l}\text { No } \\
\text { mention }\end{array}$ & Low & Violent & $\begin{array}{l}\text { Political Measures followed } \\
\text { by Surgical Strike }\end{array}$ & $\begin{array}{l}\text { Hedging } \\
\text { and Rapid } \\
\text { Escalation }\end{array}$ \\
\hline 3 & Rusk3 & Credible & Low & $\begin{array}{l}\text { Extremely } \\
\text { Violent }\end{array}$ & $\begin{array}{c}\text { Announced extensive } \\
\text { strike (declaration of war if } \\
\text { necessary) }\end{array}$ & $\begin{array}{c}\text { Rapid } \\
\text { Escalation }\end{array}$ \\
\hline 4 & Rusk4 & Credible & High & Non-violent & Blockade & Hedging \\
\hline 5 & McNamara1 & $\begin{array}{l}\text { No } \\
\text { mention }\end{array}$ & Uncertain & Undecided & Conditional Extensive Strike & $\begin{array}{l}\text { Conditional } \\
\text { Rapid } \\
\text { Escalation } \\
\end{array}$ \\
\hline 6 & McNamara2 & Credible & Low & $\begin{array}{l}\text { Extremely } \\
\text { Violent }\end{array}$ & $\begin{array}{l}\text { Unannounced Extensive } \\
\text { Strike }\end{array}$ & $\begin{array}{c}\text { Rapid } \\
\text { Escalation }\end{array}$ \\
\hline 7 & McNamara3 & Credible & Low & $\begin{array}{l}\text { Extremely } \\
\text { Violent }\end{array}$ & $\begin{array}{l}\text { Unannounced (or 24-hour } \\
\text { Warning) Extensive Strike }\end{array}$ & $\begin{array}{c}\text { Rapid } \\
\text { Escalation }\end{array}$ \\
\hline 8 & McNamara4 & Credible & High & Non-violent & Blockade and Negotiation & Hedging \\
\hline 9 & Taylor1 & $\begin{array}{l}\text { No } \\
\text { mention }\end{array}$ & Uncertain & $\begin{array}{l}\text { Extremely } \\
\text { Violent }\end{array}$ & $\begin{array}{l}\text { Unannounced Extensive } \\
\text { Strike }\end{array}$ & $\begin{array}{c}\text { Rapid } \\
\text { Escalation }\end{array}$ \\
\hline 10 & Taylor2 & $\begin{array}{l}\text { No } \\
\text { mention }\end{array}$ & Low & $\begin{array}{l}\text { Extremely } \\
\text { Violent }\end{array}$ & $\begin{array}{c}\text { Unannounced Extensive } \\
\text { Strike }\end{array}$ & $\begin{array}{l}\text { Rapid } \\
\text { Escalation }\end{array}$ \\
\hline 11 & Taylor3 & $\begin{array}{c}\text { No } \\
\text { mention }\end{array}$ & Low & $\begin{array}{l}\text { Extremely } \\
\text { Violent }\end{array}$ & $\begin{array}{l}\text { Unannounced Extensive } \\
\text { Strike }\end{array}$ & $\begin{array}{l}\text { Rapid } \\
\text { Escalation }\end{array}$ \\
\hline 12 & Taylor4 & $\begin{array}{l}\text { No } \\
\text { mention }\end{array}$ & Low & $\begin{array}{l}\text { Extremely } \\
\text { Violent }\end{array}$ & $\begin{array}{l}\text { Unannounced Extensive } \\
\text { Strike }\end{array}$ & $\begin{array}{c}\text { Rapid } \\
\text { Escalation }\end{array}$ \\
\hline 13 & Bundy1 & $\begin{array}{l}\text { No } \\
\text { mention }\end{array}$ & Uncertain & Violent & $\begin{array}{c}\text { Unannounced Surgical Strike } \\
\text { or Warning }\end{array}$ & $\begin{array}{c}\text { Gradual } \\
\text { or Rapid } \\
\text { Escalation } \\
\end{array}$ \\
\hline 14 & Bundy 2 & Credible & Low & Violent & $\begin{array}{c}\text { Unannounced Surgical Strike } \\
\text { and Negotiation }\end{array}$ & $\begin{array}{l}\text { Rapid } \\
\text { Escalation }\end{array}$ \\
\hline 15 & Bundy3 & Credible & Low & Violent & $\begin{array}{c}\text { Announced Surgical Strike } \\
\text { and Negotiation }\end{array}$ & Hedging \\
\hline
\end{tabular}




\begin{tabular}{|c|c|c|c|c|c|c|}
\hline 16 & Bundy4 & Not Clear & Low & $\begin{array}{c}\text { Extremely } \\
\text { Violent }\end{array}$ & $\begin{array}{c}\text { Unannounced Extensive } \\
\text { Strike }\end{array}$ & $\begin{array}{c}\text { Rapid } \\
\text { Escalation }\end{array}$ \\
\hline 17 & Kennedy1 & $\begin{array}{c}\text { No } \\
\text { mention }\end{array}$ & No mention & Violent & Unannounced Surgical Strike & $\begin{array}{c}\text { Rapid } \\
\text { Escalation }\end{array}$ \\
\hline 18 & Kennedy2 & Credible & High & Non-violent & $\begin{array}{c}\text { Warning, Public } \\
\text { Announcent, and Surgical } \\
\text { Strike }\end{array}$ & Hedging \\
\hline 19 & Kennedy3 & Credible & High & Non-violent & $\begin{array}{c}\text { Warning, Public } \\
\text { Snnouncement, Surgical } \\
\text { Strike, and Negotiation }\end{array}$ & Hedging \\
\hline 20 & Kennedy4 & Credible & High & Non-violent & Blockade and Negotiation & Hedging \\
\hline
\end{tabular}

* Numbers next to names indicate the four ExComm meetings from October 16 to 20, 1962.

How can we explain the divergence among the American policymakers (Table 1)? According to the Rival Hypothesis, when the challenger possesses nuclear weapons, the "crystal ball effect" gets activated, and the defender would not take any measures including use of military force. This self-containment is caused, first, by the use of violent measures that could escalate the crisis into exchanges of atomic weapons, and second, the war cost approaches negative infinity, and the probability of victory goes down to zero in nuclear wars. The Rival Hypothesis predicts that policymakers in Washington would possibly choose a gradual escalation path. This is because, first, Washington should not review violent measures due to the crystal ball effect, and second, the interest at stake is too significant to take the path of inaction.

These causal models of the Rival Hypotheses based on Rational Deterrence studies and the Nuclear Revolutionist perspective do well to explain the general pattern of American policymakers' shifting positions. However, the models show clear limitations when tested against the actual policy recommendations each ExComm member made during the initial phase of the crisis. First, the final policy decided by the ExComm was not gradual escalation but hedging, that is, the combination of non-violent use of military force and political assurance. The Soviet nuclear capability on the island did have some crystal ball effect and constrained the U.S. from deciding on the massive air assault or invasion routes. Nonetheless, the presence of Soviet nuclear weapons failed to prevent Washington from adjusting the degree of violence below the use-of-military-force level. Although the blockade was a milder punishment compared to the extensive airstrike, it did involve the use of substantial military power that could trigger a major armed conflict, possibly a nuclear war. What would have happened if the Soviet ships continued on course and the U.S. Navy started to open fire on them? As Jervis rightly explains, the blockade was not merely a signal of the American resolve but "a threat that leaves something to chance." 67

Second, the presence of Soviet nuclear missiles failed to deter ExComm advisors from advocating the airstrike option. On the contrary, most advisors asserted the necessity of forcefully removing those Soviet assets as soon as U-2 flights detected Il-28 jet bombers,

${ }_{67}$ Robert Jervis, "The Cuban Missile Crisis: What Can We Know, Why Did It Start, and How Did It End?," in The Cuban Missile Crisis: a Critical Reappraisal, ed. Len Scott and R. Gerald Hughes (New York: Routledge, 2015), 15. This theoretical term was invented by Schelling. See Schelling, The Strategy of Conflict, 187-204. 
MRBM/IRBM launchers, and cruise-missile sites on the island. They took it for granted that the U.S. should attack these bases. Their approaches diverged solely on the scope (i.e., surgical strike, general strike, and invasion) and the sequence (i.e., announced vs. surprise strike). It deserves close attention that the majority opinion was taking the rapid escalation path before a major shift occurred during the fourth ExComm meeting on October 20. The crystal ball effect only activated when CIA intelligence personnel informed the committee that some of these nuclear missiles were operational and that the Soviet bases in Cuba would be able to maintain a second-strike capability after absorbing an American airstrike.

Third, more interestingly, for Bundy and Taylor, even the possibility of the existence of the Soviet second-strike capability did not prevent them from advocating the rapid escalation route and urging extensive airstrike on all the Soviet bases in Cuba. It is fascinating to see that the introduction of nuclear weapons had no impact at all for some of the policymakers in Washington. These individuals believed that a blockade would only prevent further deployment of Soviet offensive assets to Cuba and could not do anything about the missiles that had already been deployed. The U.S. had only two options: either "trade [the missiles] out" or "go in and get them out ourselves." ${ }^{68}$ For those who did not like the idea of trading missiles, the forceful removal was the only option left despite the enormous risk it carried. In closing, the three points discussed above reject the Rival Hypothesis. Why were some ExComm members recommending the rapid escalation path of wiping out the entire Soviet bases on the island despite the MAD's strategic condition and the possibility of a nuclear holocaust?

As posited in this study's Research Hypothesis, the feasibility model predicts that Washington would not believe that the U.S.'s attempts to remove the Soviet bases in Cuba forcefully would result in a nuclear war under two conditions. These conditions include first, if Soviet nuclear retaliation were not militarily feasible, and second, as long as the Americans religiously turned to conventional forces. This explanation survives the smoking gun test. Discrepancies among policymakers in Washington precisely stemmed from their different estimation about the feasibility of the Soviet nuclear retaliation against a conventional American airstrike. The ExComm advisors recommended that Kennedy make either an announced or a surprise air strike on the Soviet missile sites in Cuba only when they believed that Moscow would most likely not use their nuclear missiles to retaliate against the U.S. attack.

For example, Rusk argued that as a nuclear attack would inevitably initiate a "general nuclear war" under MAD, Moscow should become very much restrained. ${ }^{69} \mathrm{He}$, thus, just could not "see that possibility" of Soviet nuclear retaliation. ${ }^{70}$ McNamara agreed with taking the airstrike option only when it seemed likely to destroy all the possible secondstrike capability of the Soviet forces (i.e., MiGs, airfields, nuclear storage sites, radar installations, SAM sites). ${ }^{71}$ Taylor expected that after receiving the American airstrike, the Soviets would retaliate only with "some conventional bombing." 72 This prediction allowed him to persistently support the unannounced massive air strike option even though he knew that destruction brought by the most extensive attack would "never be guaranteeing 100

\footnotetext{
68 May and Zelikow, The Kennedy Tapes, 283.

69 "Meeting on the Cuban Missile Crisis on 16 October, 1962," Tape 28, Presidential Recordings Digital Edition.

"Meeting on the Cuban Missile Crisis on 16 October, 1962," Tapes 28 and 28A, Presidential Recordings Digital Edition . Ibid.

2 Ibid.
} 
percent." ${ }^{973}$ There would always remain some Soviet nuclear missiles ready for retaliatory action. It is fascinating to find that the transcript of the ExComm meetings from October 16 to 18 is full of statements that discredit the possibility of Moscow's decision to use any surviving nuclear missiles in Cuba for reprisal.

However, the mood had changed when a few advisors pointed out that the Soviets might retaliate with atomic bombs. During the first ExComm meeting on October 16, McNamara argued that Rusk's assumption about the political prudence in using nuclear weapons was misleading because it was uncertain "what kinds of control they [the Soviets] have over the warheads." Specifically, the authority to shoot the missiles might be at the hands of the Soviet military leadership in Cuba rather than the political leaders in Moscow. In such a scenario, if U.S. fighters and bombers attacked the Soviet military command, they might press the nuclear button for defending their bases. ${ }^{74}$ Besides, when the council convened on October 18, Thompson expressed his concerns that the unannounced strike would kill many Russians, and the U.S. would "end up the whole way." " McNamara concurred with this and said, "If we've killed Russians, we're going to go in," which should result in escalation to war. If "they [the Soviets] can't stop," then the Americans probably "have to go on."76 In other words, McNamara and Thompson pictured a scenario in which nuclear missiles could be launched by the Soviet commander in Cuba when the Soviet death tolls rocketed due to massive American attacks from the sky.

Although it is not certain whether Rusk or other committee members bought their arguments, a similar rationale should have evolved within their minds for them to change their positions rapidly. The only difference from the October 18 ExComm meeting to that on October 20 was the change in intelligence report: from "not-yet operational" Soviet missiles to their state of "limited operational readiness." The fact that (1) the Soviets could manage to maintain a second-strike capability after receiving the American airstrike; and (2) an American attack would slaughter a myriad of Soviet soldiers was sufficient for most advisors in Washington to shift their policy recommendation from rapid escalation to hedging. This explanation passes the smoking gun test for McNamara's modified position because he precisely explained his rationale, and it provides the hoop evidence for other ExComm members' convergence to the blockade option.

\section{Conclusion}

Although the general trend of change in Washington's policy debate in the aftermath of deterrence failure follows the Nuclear Revolutionist prediction, the model fails to explain individual advisors' specific positions at each information set. First, most ExComm members advocated the rapid escalation path until the intelligence team confirmed that some Soviet nuclear missiles had been operational. Second, even after this confirmation, Taylor and Bundy urged Washington to take a rapid escalation path. Third, the final policy decision of Washington was hedging, rather than gradual escalation.

This mitigated impact of the "crystal ball" effect implies that threats backed by nuclear weapons are not credible until the crisis actor successfully makes the use of these weapons

\footnotetext{
73 "Meeting on the Cuban Missile Crisis on 18 October, 1962," Tapes 30 and 30A, Presidential Recordings Digital Edition.

74 "Meeting on the Cuban Missile Crisis on 16 October, 1962," Tape 28, Presidential Recordings Digital Edition.

75 "Meeting on the Cuban Missile Crisis on 18 October, 1962," Tapes 30 and 30A, Presidential Recordings Digital Edition.

76 Ibid.
} 
a feasible tool of punishment. The ExComm advisors did not "think twice" about the infeasibility of the threat as Khrushchev had expected until they realized that (1) there might be some surviving nuclear missiles ready to be launched after receiving the extensive U.S. airstrike on the Soviet bases; (2) the control of atomic warheads might not lie in the hands of politicians in Moscow, but in those of the local commander; and (3) the considerable size of Soviet ground forces in Cuba would significantly increase the number of Soviet casualties when the U.S. air force struck the island. The Soviet nuclear weapons finally began to affect the Americans' strategic thinking once these three conditions were met on October 20.

This study is not without limitations. Its most serious weakness is its limited external validity. Fortunately for humanity's sake, there have not been many observable and documented cases of nuclear war near-misses. However, the analysis compensated for this limited number of observations by increasing the number of within-case observations by disaggregating the data into individual policymakers rather than treating this crisis as a single country. In the end, however, they are all Americans. The model this research suggests, thus, needs to be tested against a broader number of cases involving different regions, periods, and possibly the nature of various international crises.

\section{Bibliography}

Allyn, Bruce J., James G. Blight, and David A. Welch. "Essence of Revision: Moscow, Havana, and the Cuban Missile Crisis.” International Security 14, no. 3 (1989-1990): 136-72.

Betts, Richard K. Nuclear Blackmail and Nuclear Balance. Washington: Brookings Institution, 1987.

Blainey, Geoffrey. The Causes of War. New York: Free Press, 1988.

Borden, William L. There Will Be No Time. New York: Macmillan, 1946.

Brady, Henry E. "Data-Set Observations versus Causal-Process Observations: the 2000 U.S. Presidential Election." In Brady and Collier, Rethinking Social Inquiry, 267-72.

Brady, Henry E., and David Collier, ed. Rethinking Social Inquiry: Diverse Tools, Shared Standards. Plymouth: Rowman \& Littlefield, 2010

Brodie, Bernard, Frederick S. Dunn, Arnold Wolfers, Percy E. Corbett, and William T. R. Fox. The Absolute Weapon. New York: Harcourt, Brace, 1946

Carnesale, Albert, Paul Doty, Stanley Hoffmann, Samuel P. Huntington, Joseph S. Nye, Jr. and Scott D. Sagan. Living with Nuclear Weapons. New York: Bantam Books, 1983.

Danilovic, Vesna. When the Stakes Are High: Deterrence and Conflict among Major Powers. Ann Arbor: University of Michigan Press, 2002.

Fearon, James D. “Selection Effects and Deterrence.” International Interactions 28 (2002): 5-29.

. "Signaling Foreign Policy Interests: Tying Hands versus Sinking Costs." Journal of Conflict Resolution 41 (1997): 68-90

Fetter, Steve. "Ballistic Missiles and Weapons of Mass Destruction: What Is the Threat? What Should be Done?" International Security 16, no. 1 (1991): 5-41.

Foreign Relations of the United States (FRUS), 1961-1963. Volume XI: Cuban Missile Crisis and Aftermath. Washington D.C.: United States Government Printing Office, 1996.

Freedman, David A. "On Types of Scientific Inquiry: The Role of Qualitative Reasoning.” In Brady and Collier, Rethinking Social Inquiry, 221-36.

Freedman, Lawrence. Deterrence. Cambridge: Polity Press, 2004.

Fursenko, Aleksandr, and Timothy Naftali. One Hell of a Gamble: Khrushchev, Castro, and Kennedy, 1958-1964. New York: W. W. Norton \& Company, 1997. 
Geller, Daniel S. "Nuclear Weapons, Deterrence, and Crisis Escalation.” Journal of Conflict Resolution 34, no. 2 (1990): 291-310.

George, Alexander, and Andrew Bennett. Case Studies and Theory Development in the Social Sciences. Boston: MIT Press, 2005.

George, Alexander, and Richard Smoke. Deterrence in American Foreign Policy. New York: Columbia University Press, 1974.

George, Alice L. The Cuban Missile Crisis: The Threshold of Nuclear Wa. New York: Routledge, 2013.

Gibson, David R. Talk at the Brink: Deliberation and Decision during the Cuban Missile Crisis. Princeton: Princeton University Press, 2012.

Goldstein, Lyle J. Preventive Attack and Weapons of Mass Destruction: A Comparative Historical Analysis. Stanford: Stanford University Press, 2006.

Gray, Colin . Nuclear Strategy and National Style. Lanham: Hamilton Press, 1986.

Harvey, Frank P. The Future's Back: Nuclear Rivalry, Deterrence Theory, and Crisis Stability after the Cold War. Montreal: McGill-Queen's University Press, 1997.

"Practicing Coercion: Revisiting Successes and Failures Using Boolean Logic and Comparative Methods." Journal of Conflict Resolution 43, no. 6 (1999): 840-71.

Huth, Paul K. "Deterrence and International Conflict: Empirical Findings and Theoretical Debates." Annual Review of Political Science 2, no. 1 (1999): 25-48.

"Extended Deterrence and the Outbreak of War." American Political Science Review 82, no. 2 (1988): 423-43.

Huth, Paul K., and Bruce Russett. "Deterrence Failure and Crisis Escalation.” International Studies Quarterly 32, no. 1 (1988): 29-45.

. "Testing Deterrence Theory: Rigor Makes a Difference.” World Politics 42, no. 4 (1990): 466-501.

“What Makes Deterrence Work? Cases from 1900 to 1980.” World Politics 36, no. 4 (1984): 496-526.

Jervis, Robert. "The Cuban Missile Crisis: What Can We Know, Why Did It Start, and How Did It End?” In The

Cuban Missile Crisis: a Critical Reappraisal, edited by Len Scott and R. Gerald Hughes, 1-39. New York: Routledge, 2015.

__. "Deterrence and Perception," International Security 7, no. 3 (1982/1983): 3-30.

"Deterrence Theory Revisited." World Politics 31, no. 2 (1979): 289-324.

- The Meaning of the Nuclear Revolution. New York: Cornell University Press, 1989.

Perception and Misperception in International Politics. Princeton: Princeton University Press, [1976] 2017.

Jervis, Robert, Richard Ned Lebow, and Janice Gross Stein. Psychology and Deterrence. Baltimore: The Johns Hopkins University Press, 1985.

King, Gary, Robert O. Keohane, and Sidney Verba. Designing Social Inquiry: Scientific Inference in Qualitative Research. Princeton: Princeton University Press, 1994.

Knopf, Jeffrey W. “The Fourth Wave in Deterrence Research.” Contemporary Security Policy 31, no.1 (2010): 1-33. Khrushchev, Sergei. Nikita Khrushchev and the Creation of a Superpower. University Park: Penn State University Press, 2000.

Lebow, Richard Ned. Between Peace and War: The Nature of International Crisis. Baltimore: Johns Hopkins University Press, 1981.

Lebow, Richard Ned, and Janice Gross Stein. "Deterrence: The Elusive Dependent Variable," World Politics 42, no.3 (1990): 336-69.

- "Rational Deterrence Theory: I Think, Therefore I Deter.” World Politics 41, no. 2 (1989): 208-24.

Luttwak, Edward N. Strategy: The Logic of War and Peace. Cambridge: Belknap Press, 2002.

May, Ernest R., and Philip D. Zelikow. The Kennedy Tapes: Inside the White House during the Cuban Missile Crisis. 
Cambridge, Mass: Belknap Press of Harvard University Press, 1997.

McAuliffe, Mary S. CIA Documents on the Cuban Missile Crisis. Darby: Diane Pub Co, 1995.

McManus, Roseanne. Statements of Resolve: Achieving Coercive Credibility in International Conflict. Cambridge: Cambridge University Press, 2017.

Morrow, James D. "Capabilities, Uncertainty, and Resolve: A Limited Information Model of Crisis Bargaining." American Journal of Political Science 33, no.4 (1989): 941-72.

Munton, Don, and David A. Welch. The Cuban Missile Crisis: A Concise History. New York: Oxford University Press, 2012.

Nitze, Paul. “Atoms, Strategy and Policy.” Foreign Affairs 34, no. 2 (1956): 187-98.

Orme, John. "Deterrence Failures: A Second Look." International Security 11, no. 4 (1987): 96-124.

Pape, Robert A. Bombing to Win: Air Power and Coercion in War. Ithaca: Cornell University Press, 1996.

Pauly, Reid B.C. "Would U.S. Leaders Push the Button? Wargames and the Sources of Nuclear Restraint." International Security 43, no. 2 (2018): 151-92.

Powell, Robert. Nuclear Deterrence Theory: The Search for Credibility. Cambridge: Cambridge University Press, 1990.

Quackenbush, Stephen L. "Deterrence Theory: Where Do We Stand?” Review of International Studies 37, no. 2 (2011): 741-62.

Sagan, Scott D. "More Will Be Worse." In Sagan and Waltz, The Spread of Nuclear Weapons, 46-88.

Sagan, Scott D., and Kenneth N. Waltz, ed. The Spread of Nuclear Weapons: A Debate Renewed. New York\& London: W.W. Norton and Company, 2003.

Schelling, Thomas C. Arms and Influence. New Haven: Yale University Press, 1966.

Sechser, Todd S., and Mathew Fuhrmann. Nuclear Weapons and Coercive Diplomacy. Cambridge: Cambridge University Press, 2017.

Slantchev, Branislav L. "Military Coercion In Interstate Crises.” American Political Science Review 99, no. 4 (2005): 533-47.

- Military Threats: the Costs of Coercion and the Price of Peace. New York: Cambridge University Press, 2011.

Snyder, Glenn H. "The Balance of Power and the Balance of Terror." In The Balance of Power, edited by Paul Seabury, 184-201. San Francisco: Chandler, 1965.

Stein, Jcanice Gross. "Rational Deterrence against 'Irrational’ Adversaries? No Common Knowledge.” In Complex Deterrence: Strategy in the Global Age, edited by T. V. Paul, Patrick M. Morgan, and James J. Wirtz. Chicago: the University of Chicago Press, 2009.

Tannenwald, Nina. "Stigmatizing the Bomb: Origins of the Nuclear Taboo." International Security 29, no. 4 (2005): $5-49$.

Waltz, Kenneth N. “More May Be Better.” In Sagan and Waltz, The Spread of Nuclear Weapons, 3-45.

."Waltz Responds to Sagan.” In Sagan and Waltz, The Spread of Nuclear Weapons, 125-54.

White, Mark J. The Kennedys and Cuba: The Declassified Documentary History. Chicago: Ivan R. Dee, 1999.

Wu, Samuel S. G. "To Attack or Not to Attack: A Theory and Empirical Assessment of Extended Immediate Deterrence." Journal of Conflict Resolution 34 (1990): 531-52.

Zagare, Frank C., and D. Marc Kilogue. Perfect Deterrence. New York: Cambridge University Press, 2000. 